\title{
SEQUENCE ANALYSIS OF THE CAPSID PROTEIN GENE OF AN ISOLATE OF Apple stem grooving virus, AND ITS SURVEY IN SOUTHERN BRAZIL
}

\author{
OSMAR NICKEL ${ }^{1}$, THOR V.M. FAJARDO ${ }^{1}$, WILHELM JELKMANN ${ }^{2} \&$ GILMAR B. KUHN $^{1}$
}

${ }^{1}$ Embrapa Uva e Vinho, Cx. Postal 130, CEP 95700-000, Bento Gonçalves, RS, e-mail: nickel@cnpuv.embrapa.br;
${ }^{2}$ Biologische Bundesanstalt für Land- und Forstwirtschaft, D-69221, Dossenheim, Germany

(Accepted for publication on 11/05/2001)

Corresponding author: Osmar Nickel

NICKEL, O., FAJARDO, T.V.M., JELKMANN, W. \& KUHN G.B. Sequence analysis of the capsid protein gene of an isolate of Apple stem grooving virus, and its survey in southern Brazil. Fitopatologia Brasileira 26:655-659. 2001.

\begin{abstract}
Apple stem grooving virus (ASGV) is one of the most important viruses infecting fruit trees. This study aimed at the molecular characterization of ASGV infecting apple (Malus domestica) plants in Santa Catarina (SC). RNA extracted from plants infected with isolate UV01 was used as a template for RT-PCR using specific primers. An amplified DNA fragment of $755 \mathrm{bp}$ was sequenced. The coat protein gene of ASGV isolate UV01 contains 714 nucleotides, coding for a protein of 237 amino acids with a predicted $\mathrm{M}_{\mathrm{r}}$ of approximately 27 $\mathrm{kDa}$. The nucleotide and the deduced amino acid sequences of the coat protein gene showed identities of $90.9 \%$ and

97.9\%, respectively, with a Japanese isolate of ASGV. Very high amino acid homologies $(98.7 \%)$ were also found with Citrus tatter leaf capillovirus (CTLV), a very close relative of ASGV. These results indicate low coat protein gene variability among Capillovirus isolates from distinct regions. In a restricted survey, mother stocks in orchards and plants introduced into the country for large scale fruit production were indexed and shown to be infected by ASGV (20\%), usually in a complex with other (latent) apple viruses (80\%). RT-PCR.

Key words: molecular characterization, Capillovirus,

\section{RESUMO}

\section{Análise da seqüência do gene da proteína capsidial de um isolado de Apple stem grooving virus, e levantamento deste no Sul do Brasil}

Apple stem grooving virus (ASGV) é um dos mais importantes vírus que infetam fruteiras de clima temperado. Este estudo teve por objetivo a caracterização molecular baseada na análise do gene da proteína capsidial do isolado ASGV UV01 encontrado em macieiras (Malus domestica) em Santa Catarina (SC). RNA extraído de plantas infetadas foi usado para a amplificação por RT-PCR, empregando-se iniciadores específicos. O fragmento amplificado de $755 \mathrm{bp}$ foi seqüenciado e comparado com outras seqüências. $\mathrm{O}$ gene da proteína capsidial do ASGV UV01 possui 714 nucleotídeos, codificando uma proteína com 237 aminoácidos de $\mathrm{M}_{\mathrm{r}}$ prevista de $27 \mathrm{kDa}$. As seqüências de nucleotídeos e de

aminoácidos deduzidos apresentaram, respectivamente, 90,9\% e 97,9\% de identidade com um isolado japonês de ASGV. Homologias de aminoácidos muito altas $(98,7 \%)$ também foram verificadas com o Citrus tatter leaf virus (CTLV), um vírus taxonomicamente próximo ao ASGV. Os resultados indicam pequena variabilidade entre isolados de Capillovirus de diferentes regiões. Em um levantamento restrito, plantas adultas usadas como matrizes e mudas introduzidas no país para produção de frutos foram indexadas e mostraram-se infetadas com ASGV (20\%), geralmente em complexo com outros vírus (latentes) da macieira $(80 \%)$.
\end{abstract}

Apple stem grooving virus (ASGV) genus Capillovirus is disseminated worldwide in Rosaceae fruit trees such as apple (Malus domestica Borkh.), pear (Pyrus communis Linnaeus), apricot (Prunus armeniaca Linnaeus) and cherry (Prunus avium Linnaeus), usually causing a latent infection in most commercial cultivars. The virus is the type-species of the genus Capillovirus, has flexuous, filamentous particles of approximately $620 \times 12 \mathrm{~nm}$ and a positive-sense, ssRNA genome with 6496 nucleotides (Yoshikawa \& Takahashi, 1988; Yanase et al., 1990; Yoshikawa et al., 1992).
Although usually latent in most commercial varieties, ASGV symptoms in susceptible Malus species include severe xylem pitting and grooving with pegs protruding on inner bark face, phloem necrosis, reduced vigor of the canopy and an overall decline of the plant. Scions and interstocks do not usually show wood symptoms. Plants grafted with infected material display poor budwood welding, develop poorly, and either die at the nursery or decline at the orchard. ASGV, probably associated with Apple chlorotic leafspot virus (ACLSV) genus Trichovirus, is the causal agent of this decline 
(Yanase, 1983; Kinard et al., 1996; Nickel et al., 1999). Precocious decline and death are apparently a function of strain virulence and host susceptibility.

Here we report on the characterization of the coat protein gene of ASGV isolate UV01 (Nickel et al., 1999) by nucleotide sequence analysis, as well as on results of a restricted survey of apple propagating material in Southern Brazil.

\section{Virus source and restricted survey}

Detection and symptomatology of ASGV isolate UV01, collected in Fraiburgo, state of Santa Catarina (SC) have been reported (Nickel et al., 1999). The virus isolate was mechanically transmitted to Chenopodium quinoa Willd. and Nicotiana occidentalis Wheeler cv. 37B.

In Vacaria, State of Rio Grande do Sul (RS), São Joaquim and Fraiburgo (SC), budwood mother plants of private commercial orchards or plants introduced for large scale planting were indexed on Malus domestica $\mathrm{cv}$. Virginia $\mathrm{Crab}$ for the presence of ASGV. The same samples were additionally indexed on cv. Russian Seedling 12740.7A (for ACLSV) and cv. Spy 227 (for Spy Epinasty and Decline, SED/ Apple stem pitting virus, ASPV) genus Foveavirus (Stouffer, 1989), and indicator plants were kept in a screenhouse. The following varieties were evaluated:

Orchard 1, Fraiburgo, SC (origin of germplasm, where available, is given in brackets following the cultivar's name): Imperatriz, Pacific Rose, Pink Lady, Braeburn, Belgolden, Lizgala (Caçador, SC), Baronesa (Caçador, SC), Imperial Gala (Curitiba, PR), Fuji Suprema (Caçador, SC), Fred Hough, and the rootstock Maruba-kaido [M. prunifolia (Willd.) Borkh. var. ringo] (one sample each). Orchard 2, Vacaria, RS: Braeburn (Netherlands, NL), Jonagored (NL), Gala Must (NL), Imperial Gala (USA), Royal Gala, Mondial Gala (France), Royal Gala Tenroy, Fuji Irradiada (Japan, J), Fuji 1 (NL), and rootstock M7 (1 sample each). Orchard 3, Vacaria, RS: Hillvel, one sample. Orchards 4 and 8, São Joaquim, SC: Fuji, six samples each. Orchard 6, São Joaquim, SC: Golden Delicious, one sample. Sampling was carried out in March through October 1999. Evaluation of indicator reactions was carried out during the first growth flush, and repeated twice a year in the last two years.

\section{Nucleic acid extraction and primers}

Total RNA was extracted from infected leaves of $N$. occidentalis cv. 37B, C. quinoa and Malus spp. by capture on silica particles as described previously (Nickel et al., 1999) and used as a template for RT-PCR with specific primers for ASGV amplification.

The following primer sequences were synthesized, according to published nucleotide sequences of ASGV (Yoshikawa et al., 1992; MacKenzie et al., 1997) as well as GenBank data: ASGV6396 (reverse), 5' CTG CAA GAC CGC GAC CAA GTT T 3' and ASGV5641 (forward), 5' ATG AGT TTG GAA GAC GTG CTT C 3', yielding an amplification product of 755 base pairs (bp).
For assays of budwood mother plants and orchard plants, PCR primers ASGV6396 and ASGV5873 (5' CCC GCT GTT GGA TTT GAT ACA CCT C 3') (MacKenzie et al., 1997), yielding an amplification product of $523 \mathrm{bp}$, were also used. Since ACLSV was also expected to be associated with the plant decline syndrome, amplification with primers 5' ATG GCG GCA GTG CTG AAC CTC C 3' (ACLSV6784, forward) and 5' ATG TTG ACT AGA AAC GCA AAT C 3' (ACLSV7365, reverse), with an expected fragment size of $581 \mathrm{bp}$, was also attempted. ACLSV primers were synthesized according to GenBank data.

\section{cDNA synthesis, PCR, cloning, and sequencing of the coat protein gene}

Reverse transcription, PCR amplification, and analysis of amplification products were carried out as described previously (Nickel et al., 1999). The amplified fragment with 755 bp was cloned into a Bluescript SKII (Stratagene) -based T-overhang vector and used to transform competent DH5 $\alpha$ Escherichia coli cells. Ampicillin-resistant transformants were selected and plasmids containing an insert of the expected size were isolated from overnight cultures of recombinant bacteria by alcaline cell lysis (Sambrook et al., 1989). Purified plasmid DNA was sequenced on an automated sequencer and sequence data were compiled and analyzed using the GCG software package from the University of Wisconsin (Devereux et al., 1984). Search and alignment of the sequenced clone were also carried out in the GenBank and EMBL databases.

The expected 755 bp DNA fragment comprising the entire coat protein gene and $41 \mathrm{bp}$ of the 3 ' non-coding region of ASGV UV01 was successfully amplified. The open reading frame (ORF) of ASGV coat protein gene contains 714 nucleotides, coding for a protein of 237 amino acids (Figure 1) with a predicted $M_{r}$ of about $27 \mathrm{kDa}$. This gene product corresponds in size to the coat protein of other isolates of ASGV and of Citrus tatter leaf virus (CTLV) (Yoshikawa \& Takahashi, 1988; Ohira et al., 1995) a closely related Capillovirus that can cause graft incompatibility in Citrus spp.

Comparing the nucleotide sequence of the ASGV UV01 coat protein gene with other isolates, a 93.3\% and 90.9\% identity was found with CTLV and a Japanese ASGV isolate, respectively. The identity of the deduced amino acid sequence with CTLV and ASGV-Japan was of $98.7 \%$ and $97.9 \%$, respectively (Table 1). These results indicate a low variability of coat protein gene sequence among isolates from distinct geographical regions, allowing use of primers based on published sequences of American and Japanese ASGV strains, indicating that these isolates are closely related. Considering the high similarities displayed between ASGV, including isolate UV01, and CTLV, it has been proposed that both should be regarded as strains of the same virus species rather than different capilloviruses (Ohira et al., 1995). This is supported by the identity of $94 \%$ for the 3 ' non-coding region and of $88.5 \%$ and $94.7 \%$ for ORF1 (polyprotein of $242 \mathrm{kDa}$ ) and ORF2 (36 kDa movement protein), respectively, 


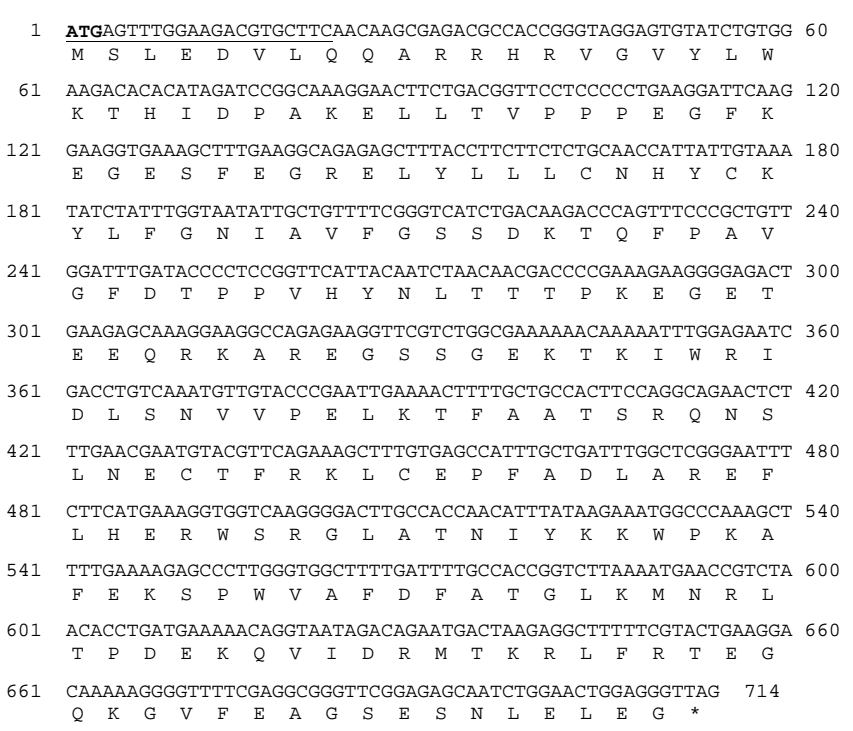

FIG. 1 - Nucleotide sequence of the coat protein gene of Apple stem grooving virus UV01 isolate. Deduced amino acid sequence of the coat protein gene is shown below the nucleotide sequence. Boldface and asterisk indicate start and termination codons, respectively. ASGV5641 is the 5' forward primer (underlined).

between ASGV and CTLV, as well as serological crossreactivity and the ability of ASGV to infect citrus and to induce CTLV-like symptoms in these hosts (Ohira et al., 1994). However CTLV and ASGV have unique host preferences in different climates, and it is still not known whether CTLV can infect apple trees. Both viruses also resemble each other in their experimental host ranges and in the symptoms induced in herbaceous plants (Yoshikawa et al., 1993; Ohira et al., 1995).

The high similarity between isolate UV01 and ASGV

TABLE 1 - Pairwise percent identities among coat protein amino acid sequences (above diagonal) and coat protein nucleotide sequences (below diagonal) of Apple stem grooving virus isolate UV01 and other related viruses

\begin{tabular}{|c|c|c|c|c|c|}
\hline & $\begin{array}{c}\text { ASG V UV01 } \\
714 \mathrm{bp}\end{array}$ & $\begin{array}{l}\text { CTLV }^{(1)} \\
\text { D14455 }\end{array}$ & $\begin{array}{l}\text { CTLV }^{(2)} \\
\text { D16368 }\end{array}$ & $\begin{array}{l}\text { CTLV }^{(3)} \\
\text { D16681 }\end{array}$ & $\begin{array}{l}\text { ASG V }^{(4)} \\
\text { D14995 }\end{array}$ \\
\hline $\begin{array}{l}\text { ASG V UV01 } \\
714 \text { b p }\end{array}$ & $e_{1}$ & 98.7 & 98.7 & 98.7 & 97.9 \\
\hline $\begin{array}{l}\text { CTLV }^{(1)} \\
\text { D14455 }\end{array}$ & 93.3 & -- & 100.0 & 100.0 & 98.3 \\
\hline $\begin{array}{l}\text { CTLV }^{(2)} \\
\text { D16368 }\end{array}$ & 93.3 & 99.1 & -- & 100.0 & 98.3 \\
\hline $\begin{array}{l}\text { CTLV } \\
\text { D } 16681\end{array}$ & 93.3 & 100.0 & 99.0 & -- & 98.3 \\
\hline $\begin{array}{l}\operatorname{ASG~V}^{(4)} \\
\text { D14995 }\end{array}$ & 90.9 & 86.3 & 86.1 & 82.9 & -- \\
\hline
\end{tabular}

Access: ASGV UV01: Brazilian isolate of ASGV.

(1) Ohira et al. (1994) (L-isolate); (2) Yoshikawa et al. (1993) (Li-23 isolate); (3) Ohira et al. (1995) (L-isolate); (4) Yoshikawa et al. (1992) (isolate P-209). GenBank database access code closed to virus name. and CTLV isolates from different geographic regions and different hosts agrees with the finding that there is no phylogenetic correlation between isolates or sequence variants of capilloviruses within a cluster, on one side, and the host species from which the viruses were originally isolated, on the other (Magome et al., 1997). Similarly to the results presented here, Kinard et al. (1996) described that ASGV fragments amplified from apple, cherry, and Asian pear [Prunus pyrifolia Burm. f. Nakai (P. serotina Rehd.)] exhibited high nucleotide identities $(\geq 88.5 \%)$ to the corresponding region of an apple ASGV isolate from Japan, with identities with CTLV being higher $(\geq 91.4 \%)$.

In contrast to the high similarities of the coat protein and movement protein genes among isolates and sequence variants, the so called "variable region", considered to be characteristic of the genus Capillovirus genome organization, displays considerable variability among isolates (Magome et al., 1997). These authors suggest that a phylogenetic tree based on this region should reflect more precisely the evolutionary relationships among isolates. Sequencing of this region of isolate UV01 will probably reveal the origin of this Brazilian isolate and allow its grouping with other isolates.

Symptoms on apple field plants can not generally be correlated to a specific virus, since infections usually occur as complexes of more than one pathogen. ASGV often appears in mixed infections with ACLSV, both widespread in apple germplasm in Brazil. In one case, ASGV UV01 alone was clearly correlated with the death of nursery plants in the absence of ACLSV. This conclusion was supported by negative PCR amplification attempts (Nickel et al., 1999).

In Brazil, propagative material is collected from nonindexed elite trees that growers themselves select in their orchards, widely grafted on rootstocks tolerant to latent viruses. With the recent trend to a shift over to the highly productive and precocious Maruba-kaido rootstock, widespread infections with ASGV and other latent viruses became visible. Checking orchard trees used by growers as budwood mother plants on Virginia Crab and other indicator plants confirmed the presence of viruses (ASGV, ACLSV and SED/ASPV) in $80 \%$ of the varieties tested, while around $20 \%$ carried ASGV (Royal Gala, Fuji, Fuji 1, Fuji Irradiada, Fuji Suprema, Golden Delicious and M7) (Table 2). Evaluation of the remaining, symptomless cvs. is proceeding for two more growth flushes.

These results reveal that a considerable part of the propagative material in use by the apple industry in Southern Brazil is infected with at least two viruses, ASGV and ACLSV. It is relevant in this context that tissues were sampled at wellmanaged properties. Despite this fact, probably because of the use of virus-tolerant rootstocks, Brazilian apple production has been increasing considerably in recent decades and in 2000 has reached approximately 850,000 tons (Brazilian Apple Growers Association, ABPM) mainly through the introduction of technological advancements and a substantial expansion of the area planted. Such a vigorously growing industry could maximize its economic returns if supplied with 
O. Nickel et al.

TABLE 2 - Apple (Mallus domestica) varieties collected in SC and RS evaluated for the presence of Apple stem grooving virus, Apple chlorotic leaf spot virus and SED/ Apple sterm pitting virus*

\begin{tabular}{|c|c|c|c|c|}
\hline Variety & $\begin{array}{l}\text { Origin of } \\
\text { sample }\end{array}$ & $\begin{array}{c}\text { Site of } \\
\text { collection }\end{array}$ & $\begin{array}{c}\text { Date of } \\
\text { collection }\end{array}$ & Virus detected \\
\hline Baronesa & Fraiburgo (Caçador) & Orchard 1 & 03.99 & symptomless \\
\hline Belgolden & Fraiburgo & Orchard 1 & 03.99 & ACLSV \\
\hline Braeburn & Vacaria (Netherlands) & Orchard 2 & 05.99 & SED/A SPV, ACLSV \\
\hline Braeburn & Fraiburgo & Orchard 1 & 03.99 & symptomless \\
\hline Fred Hough & Fraiburgo & Orchard 1 & 09.99 & ACLSV \\
\hline Fuji & São Joaquim & Orchard 4 & 10.99 & ASGV, ACLSV \\
\hline Fuji & São Joaquim & Orchard 8 & 10.99 & ACLSV \\
\hline Fuji 1 & Vacaria (Netherlands) & Orchard 2 & 05.99 & ASGV, ACLSV \\
\hline Fuji Irradiada & Vacaria (Japan) & Orchard 2 & 05.99 & ASGV, ACLSV \\
\hline Fuji Suprema & Fraiburgo (Caçador) & Orchard 1 & 03.99 & ASGV, ACLSV, SED/ASPV \\
\hline Gala Must & Vacaria (Netherlands) & Orchard 2 & 05.99 & ACLSV \\
\hline Golden Delicious & São Joaquim & Orchard 6 & 03.99 & ASGV, ACLSV \\
\hline Hillvel & Vacaria & Orchard 3 & 05.99 & symptom less \\
\hline Imperatriz & Fraiburgo & Orchard 1 & 03.99 & ACLSV \\
\hline Imperial Gala & Fraiburgo (Curitiba) & Orchard 1 & 03.99 & ACLSV, SED/ASPV \\
\hline Imperial Gala & Vacaria (USA) & Orchard 2 & 05.99 & SED/ASPV \\
\hline Jonagored & Vacaria (Netherlands) & Orchard 2 & 05.99 & SED/A SPV \\
\hline Lizgala & Fraiburgo (Caçador) & Orchard 1 & 03.99 & symptomless \\
\hline M 7 & Vacaria & Orchard 2 & 09.99 & A S G V \\
\hline M aruba-kaido & Fraiburgo & Orchard 1 & 09.99 & healthy \\
\hline Mondial Gala & Vacaria (France) & Orchard 2 & 05.99 & ACLSV \\
\hline Pacific Rose & Fraiburgo & Orchard 1 & 03.99 & symptomless \\
\hline Pink Lady & Fraiburgo & Orchard 1 & 03.99 & symptomless \\
\hline Royal Gala & Vacaria & Orchard 2 & 05.99 & ASGV, SED/ASPV \\
\hline Royal Gala Tenroy & Vacaria & Orchard 2 & 05.99 & SED/ASPV \\
\hline
\end{tabular}

*One sample each, except orchards 4 and 8 with six samples.

**In brackets, where available, the origin of the germplasm is given.

virus-free propagative material in order to exploit all productive and environmental advantages of healthy, virusfree plants.

\section{LITERATURE CITED}

DEVEREUX, J., HAEBERLI, P. \& SMITHIES, O. A comprehensive set of sequence analyses programs for the VAX. Nucleic Acids Research 12:387-395.1984.

KINARD, G.R., SCOTT, S.W. \& BARNETT, O.W. Detection of Apple chlorotic leaf spot and Apple stem grooving viruses using RT-PCR. Plant Disease 80:616-621. 1996.

MAGOME, H., YOSHIKAWA, N., TAKAHASHI, T., ITO, T. \& MIYAKAWA, T. Molecular variability of the genomes of capilloviruses from apple, Japanese pear, European pear, and citrus trees. Phytopathology 87:389396. 1997.

MACKENZIE, D.J., MACLEAN, M.A., MUKERJI, S. \& GREEN, M. Improved RNA extraction from woody plants for the detection of viral pathogens by reverse transcription-polymerase chain reaction. Plant Disease 81:222-226. 1997.
NICKEL, O., JELKMANN, W. \& KUHN, G. Occurrence of Apple stem grooving capillovirus in Santa Catarina, Brazil, detected by RT-PCR. Fitopatologia Brasileira 24:444-446. 1999.

OHIRA, K., ITO, T., KAWAI, A., NAMBA, S., KUSUMI, T. \& TSUCHIZAKI, T. Nucleotide sequence of the 3' terminal region of Citrus tatter leaf virus RNA. Virus Genes 8:169-172. 1994.

OHIRA, K., NAMBA, S., ROZANOV, M., KUSUMI, T. \& TSUCHIZAKI, T. Complete sequence of an infectious full-length cDNA clone of Citrus tatter leaf capillovirus: comparative sequence analysis of Capillovirus genomes. Journal of General Virology 76: 2305-2309. 1995.

SAMBROOK, J., FRITSCH, E.F. \& MANIATIS, T. Molecular Cloning - A Laboratory Manual. Second edition. New York. Cold Spring Harbor Laboratory Press. 1989.

STOUFFER, R.F. Apple stem pitting. In: Fridlund, P.R. (Ed.). Virus and viruslike diseases of pome fruits and simulating noninfectious disorders. Washington State University. Pullman. 1989. pp. 138-144.

YANASE, H. Back-transmission of Apple stem grooving virus 
Sequence analysis of the capsid protein gene of an isolate...

to apple seedlings and induction of symptoms of apple topworking disease in Mitsuba kaido (Malus sieboldii) and Kobano zumi (Malus sieboldii var. arborescens) rootstocks. Acta Horticulturae 130:117-122. 1983.

YANASE, H., MINK, G.I., SAWAMURA, K. \& YAMAGUCHI, A. Apple topworking disease. In: Jones, A.L. \& Aldwinckle, H.S. (Eds.). Compendium of Apple and Pear Diseases. St. Paul. APS Press. 1990. pp. 74-75.

YOSHIKAWA, N. \& TAKAHASHI, T. Properties of RNAs and proteins of Apple stem grooving and Apple chlorotic leaf spot viruses. Journal of General Virology 69: 241245. 1988.

YOSHIKAWA, N., SASAKI, E., KATO, M. \& TAKAHASHI, T. The nucleotide sequence of Apple stem grooving capillovirus genome. Virology 191:98-105.1992.

YOSHIKAWA, N., IMAIZUMI, M., TAKAHASHI, T. \& INOUYE, N. Striking similarities between the nucleotide sequence and genome organization of Citrus tatter leaf and Apple stem grooving capilloviruses. Journal of General Virology 74:2743-2747. 1993. 